\title{
Morbidity and mortality in preterm infants less than 29 weeks of gestational age
}

\author{
Beatriz Riquito Marques ${ }^{1}$, Ana Clara Dinis', Gustavo Rochaa, ${ }^{1,2}$ Filipa \\ Flôr-de-Lima ${ }^{1,2}$, Ana Cristina Matos ${ }^{3,4}$, Carla Henriques ${ }^{3,5}$, Hercília \\ Guimarães ${ }^{1,2,6}$
}

\author{
${ }^{1}$ Faculty of Medicine, University of Porto, Porto, Portugal \\ ${ }^{2}$ Neonatal Intensive Care Unit, Centro Hospitalar São João, Porto, Portugal \\ ${ }^{3}$ School of Technology and Management, Polytechnic Institute of Viseu, Viseu, Portugal \\ ${ }^{4}$ Center for the Study of Education, Technologies and Health, Viseu, Portugal \\ ${ }^{5}$ Center for Mathematics, University of Coimbra, Coimbra, Portugal \\ ${ }^{6}$ Cardiovascular R\&D Unit of Faculty of Medicine, University of Porto, Porto, Portugal
}

\begin{abstract}
Background: Preterm birth is certainly a public health problem. Aside from being an important cause of mortality, prematurity increases the risk of serious lifetime disabilities.

Objective: To assess the overall survival, causes of death and neonatal morbidities associated with prematurity of newborns less than 29 weeks of gestational age (GA).

Methods: Retrospective study including all preterm infants less than 29 weeks of GA admitted to the level III Neonatal Intensive Care Unit (NICU) at Centro Hospital São João in Porto, Portugal, between January $1^{\text {st }}, 2005$ and December $31^{\text {st }}, 2016$. Newborns were grouped into three groups according to their GA: G23 $3^{+0}-24^{+6}, \mathrm{G} 25^{+0}-26^{+6}, \mathrm{G} 27^{+0}-28^{+6}$.

Results: In this 12-year-period, 160 preterm neonates less than 29 weeks of GA admitted to this NICU met our inclusion criteria. Overall deaths were $60(37.5 \%)$, variating between $25(92.6 \%)$ in the $\mathrm{G} 23^{+0}-24^{+6}, 23(46 \%)$ in the $\mathrm{G} 25^{+0}-26^{+6}$ and $12(14.5 \%)$ in the $\mathrm{G} 27^{+0}-28^{+6}$. The leading causes of death were intraventricular hemorrhage (IVH) and sepsis. Early neonatal mortality was $20.6 \%$. Among survivors, $41 \%$ had bronchopulmonary dysplasia (BPD), $69 \%$ developed late sepsis, $56 \%$ retinopathy of prematurity (ROP), $44 \%$ IVH and $10 \%$ cystic periventricular leukomalacia (cPVL).

Conclusions: Mortality rates in this preterm group were high in spite of all the technological and scientific advances. Pulmonary conditions (respiratory distress syndrome and BPD), sepsis and neurologic outcomes (ROP, IVH and cPVL) were still major causes of morbidity. In line with other series, the limit of viability in this cohort of preterm infants is 25 weeks of GA. Prenatal, perinatal and postnatal care still all have a long road ahead, especially when it comes to these "gray zone" newborns.
\end{abstract}




\section{Keywords}

Preterm infant, mortality, morbidity, limit of viability, Neonatal Intensive Care Unit, bronchopulmonary dysplasia.

\section{Corresponding author}

Beatriz Riquito Marques, Department of Gynecology-Obstetrics and Pediatrics, Faculty of Medicine, University of Porto, Alameda Professor Hernâni Monteiro, 4200-319 Porto, Portugal; telephone number: +35122551 3600; fax number: +351 22551 3601; email addresses: mimed12269@med.up.pt, beatrizriquito@gmail.com.

\section{How to cite}

Marques BR, Dinis AC, Rocha G, Flôr-de-Lima F, Matos AC, Henriques C, Guimarães H. Morbidity and mortality in preterm infants less than 29 weeks of gestational age. J Pediatr Neonat Individual Med. 2019;8(1):e080110. doi: 10.7363/080110.

\section{Introduction}

Preterm birth is certainly a public health problem. According to the World Health Organization (WHO), prematurity is the leading cause of death among newborns and it comes in second between children below five years old, after pneumonia. Aside from being an important cause of mortality, premature birth increases the risk of serious lifetime disabilities [1].

Prematurity and its poor outcomes not only occur at high rates in undeveloped countries but also have a significant impact in the more developed ones. In Portugal, for instance, $7.8 \%$ of all children born in 2016 were preterm, and 2.3/1,000 babies died before 28 days of life [2].

The limit of viability has been considerably decreasing from 31 weeks in 1960 to 23 weeks of gestational age (GA) nowadays [3], due to improvements in advanced life support technologies. However, this increase in survival rate has consequently raised the absolute number of premature infants with chronic morbidities.

There are numerous ways to fight these devastating outcomes of preterm newborns. One of them is to prevent preterm births through preconception and antenatal care; another one is to increase neonatal care quality, mainly in the Neonatal Intensive Care Units (NICUs).

A systematic review showed that there is still a wide variation of recommendations among countries, although with an overall agreement for comfort care at 22 weeks of GA and active care at 25 weeks of GA [4].

The aim of this study was to assess the overall survival, causes of death and neonatal morbidities associated with prematurity of newborns less than 29 weeks of GA, in a level III NICU.

\section{Methods}

We conducted a retrospective study including all preterm infants born with less than 29 weeks of GA who were admitted to the level III NICU at hospital São João in Porto, Portugal, one of the 20 level III hospitals in the country. Data were collected from the past 12 years, between January $1^{\text {st }}, 2005$ and December 31 $1^{\text {st }}, 2016$. We decided to exclude all newborns admitted after 72 hours of life and also those transferred to other centers before their first week of life. Clinical data, including demographic, obstetric and neonatal were collected through a retrospective search of the medical records available either on paper or electronic database.

GA was assessed by menstrual age (regular menstrual cycles), obstetric ultrasound examination [5] or the New Ballard Score (in the absence of obstetric data) [6]. Fetal growth restriction was defined as a birth weight below the $10^{\text {th }}$ percentile of Fenton's fetal growth charts [7].

In this center, antenatal steroid regimen is performed with betamethasone since 2003 in pregnancies below 25 weeks of GA, in which preterm birth is a possibility [8].

We collected data on several conditions associated with prematurity. Respiratory distress syndrome (RDS) was diagnosed according to the European Consensus Guidelines on the Management of Neonatal Respiratory Distress Syndrome: $\mathrm{PaO}_{2}<50 \mathrm{mmHg}$ in room air, central cyanosis in room air, need for supplemental oxygen to maintain $\mathrm{PaO}_{2}>50 \mathrm{mmHg}$ or to maintain a pulse oximeter saturation $>85 \%$ within the first 24 hours of life; and as well as the classical chest radiograph (including a ground-glass appearance and air bronchogram). Nonetheless, this classic patterns of RDS are rarely seen today due to early surfactant therapy and early continuous positive air pressure (CPAP) [9-11]. Newborns were accessed at 36 weeks of GA or at discharge to determine whether they had bronchopulmonary dysplasia (BPD). BPD was defined as treatment with supplemental oxygen for at least 28 days and classified in mild, moderate or severe according 
to the National Institute of Child Health and Human Development (NICHD) [12]. Pulmonary hemorrhage and pneumonia were diagnosed based on clinical and radiological findings, the latter being also based on a microbiological culture. Hemodynamically significant patent ductus arteriosus (PDA) was diagnosed between 24 and 72 hours of life based on clinical symptoms and echocardiographic findings. The infants were treated with indomethacin before 2010 and with ibuprofen afterward or with surgical closure when medical treatment failed or was contraindicated. We defined and staged necrotizing enterocolitis (NEC) according to Bell's criteria [13]. Early and late-onset sepsis were considered when there were evident clinical symptoms of sepsis and a positive C-reactive protein, confirmed or not with a positive blood culture, before or after the first 72 hours of life. The diagnosis and grading of intraventricular hemorrhage (IVH) were based on Papile's [14] or Volpe's [15] classification depending on the year of birth (before or after 2010, respectively) and grade III and IV were considered severe. Cystic periventricular leukomalacia (cPVL) was classified according to De Vries [16]. Retinopathy of prematurity (ROP) was diagnosed and classified according to the international classification [17].

We also registered all management and mortality information. Necropsy data of deceased neonates were also registered and analyzed, whenever parents authorized it.

We divided the newborns into three groups of two weeks of age each according to their GA: $\mathrm{G} 23^{+0}-24^{+6}, \mathrm{G} 25^{+0}-26^{+6}$, and $\mathrm{G} 27^{+0}-28^{+6}$. We focused our study on data after 2005 because there were a few major changes in the NICU concerning the management of preterm newborns [8].

This study was approved by the Ethics Committee of Centro Hospitalar São João, number 180-17.

Data were statistically analyzed using SPSS ${ }^{\circledR}$ version $24 \mathrm{IBM} \circledast$ software.

It was considered statistically significant a $\mathrm{p}$-value $\leq 0.05$. Categorical variables are presented as percentages and numerical variables as median with an inter-quartile range. Univariate analysis comprised the Mann-Whitney U-test or KruskalWallis to compare groups for numerical variables and the Chi-square test or Fisher's exact test for categorical variables.

A multivariate analysis was conducted to identify predictors of death, with a $95 \%$ confidence interval
(CI). Logistic regression models were constructed beforehand, including all covariates identified in the univariate analysis with $\mathrm{p}$-value $<0.1$.

\section{Results}

About 3,000 newborns are born at Centro Hospital São João each year, and 450 are admitted to its level III NICU, including both inborn and outborn infants. In our 12-year-period, 160 preterms with less than 29 weeks of GA were admitted to the NICU and met our inclusion criteria.

Among the 160 neonates, 74 (46.3\%) were female and $112(70 \%)$ were singletons. Mother's median age was 31 years, and $60.6 \%$ of the babies were delivered by a cesarean section (C-section), a high rate which does not mirror the global rates of this country, currently about $30 \%$. Prenatal corticosteroids were administered to 141 (91.6\%), Tab. 1.

Everyone received supplemental oxygen and ventilation, either with nasal continuous positive airway pressure (nCPAP) or with invasive mechanical ventilation (IMV). Over these 12 years, we found a trend to decrease the endotracheal intubation in the delivery room from $97 \%$ before 2010 to $89 \%$ afterward, $p=0.059$. In this study, we did not find any significant difference between the use of IMV, being $91.2 \%$ and $88 \%$, before and after 2010, respectively. Surfactant therapy was administered to $150(94.9 \%)$ preterm infants. Dopamine was administered to $16(61.5 \%)$ and 26 $(52 \%)$ in the first two groups $\left(\mathrm{G} 23^{+0}-24^{+6}\right.$ and $\mathrm{G} 25^{+0}$ $26^{+6}$, respectively), and to $26(31.3 \%)$ in the third group $\left(\mathrm{G} 27^{+0}-28^{+6}\right)$. Based on the data we collected, all infants received antibiotics (Tab. 2).

Overall deaths were $60(37.5 \%)$, variating between $25(92.6 \%)$ in the $\mathrm{G} 23^{+0}-24^{+6}, 23(46 \%)$ in the $\mathrm{G} 25^{+0}-26^{+6}$ and $12(14.5 \%)$ in the $\mathrm{G} 27^{+0}-28^{+6}$. The leading causes of death were IVH and sepsis. Early neonatal mortality was $20.6 \%$, and $45.5 \%$ of these newborns died because of pulmonary hypoplasia (Tab. 3).

In a logistic regression followed by a multivariable analysis, death was significantly associated with GA $(\mathrm{B}=0.355 ; 95 \% \mathrm{CI}=0.226$ $0.557 ; \mathrm{p}<0.0005)$ and birth weight $(\mathrm{B}=0.996 ; \mathrm{CI}$ $=0.993-0.999 ; \mathrm{p}<0.0005)$ but not with prenatal steroids or surfactant $(p>0.05)$. Based on the B value $=0.355$, the chances of death decrease $64.5 \%$ for each additional week of GA.

Global rates of RDS were close to $89 \%$ and BPD was seen in 35 (21.9\%) of all infants included in the 
Table 1. Maternal and newborn's demographics and perinatal clinical data.

\begin{tabular}{|c|c|c|c|c|c|}
\hline GA (weeks) & $\begin{array}{c}\text { Total } \\
(n=160)\end{array}$ & $\begin{array}{l}23^{+0}-24^{+6} \\
(n=27)\end{array}$ & $\begin{array}{l}25^{+0}-26^{+6} \\
(\mathrm{n}=50)\end{array}$ & $\begin{array}{l}27^{+0}-28^{+6} \\
(n=83)\end{array}$ & p \\
\hline Mother's age, median (IQR) & $31(28-35)$ & $32(31-36)$ & $31(28-33)$ & $31(28-35)$ & $0.246^{b}$ \\
\hline $\begin{array}{l}\text { Gender } \\
\text { - Male, n (\%) } \\
\text { - Female, n (\%) }\end{array}$ & $\begin{array}{l}86(53.8) \\
74(46.3)\end{array}$ & $\begin{array}{l}16(59.3) \\
11(40.7)\end{array}$ & $\begin{array}{l}28(56.0) \\
22(44.0)\end{array}$ & $\begin{array}{l}42(50.6) \\
41(49.4)\end{array}$ & $0.683^{\mathrm{a}}$ \\
\hline BW (g), median (IQR) & $835(690-1,000)$ & $650(560-700)$ & $790(700-880)$ & $985(805-1,150)$ & $<0.0005^{b}$ \\
\hline Fetal growth restriction, n (\%) & $30(18.8)$ & $3(11.1)$ & $8(16.0)$ & $19(22.9)$ & $0.330^{a}$ \\
\hline $\begin{array}{l}\text { Parity } \\
\text { • Single, n (\%) } \\
\text { - Multiple, n (\%) }\end{array}$ & $\begin{array}{l}112(70.0) \\
48(30.0)\end{array}$ & $\begin{array}{l}12(44.4) \\
15(55.6)\end{array}$ & $\begin{array}{l}37(74.0) \\
13(26.0)\end{array}$ & $\begin{array}{l}63(75.9) \\
20(24.1)\end{array}$ & $0.006^{a}$ \\
\hline $\begin{array}{l}\text { Delivery } \\
\text { • C-section, n (\%) }\end{array}$ & $97(60.6)$ & $3(11.1)$ & $30(60.0)$ & $64(77.1)$ & $<0.0005^{a}$ \\
\hline $\begin{array}{l}\text { Prenatal steroids, n (\%) } \\
\text { - Full cycle, } \mathbf{n}(\%)\end{array}$ & $\begin{array}{l}141(91.6) \\
109(77.3)\end{array}$ & $\begin{array}{l}19(73.1) \\
11(57.9)\end{array}$ & $\begin{array}{l}44(95.7) \\
34(77.3)\end{array}$ & $\begin{array}{l}78(95.1) \\
64(82.1)\end{array}$ & $\begin{array}{l}0.004^{c} \\
0.079^{a}\end{array}$ \\
\hline Mother's infection, n (\%) & $28(17.6)$ & $2(7.4)$ & $8(16.0)$ & $18(22.0)$ & $0.213^{a}$ \\
\hline Antibiotic use, $\mathrm{n}(\%)$ & $63(39.4)$ & $6(22.2)$ & $16(32.0)$ & $41(49.4)$ & $0.019^{a}$ \\
\hline $\begin{array}{l}\text { Mother's disease, } \mathrm{n}(\%) \\
\text { - Autoimmune disease } \\
\text { - Arterial hypertension } \\
\text { - Gestational diabetes } \\
\text { - Preeclampsia } \\
\text { - Eclampsia } \\
\text { - HELLP dyndrome } \\
\text { - Placental abruption }\end{array}$ & $\begin{array}{c}4(2.5) \\
10(6.3) \\
14(8.8) \\
24(15.1) \\
1(0.6) \\
6(3.8) \\
21(13.1)\end{array}$ & $\begin{array}{l}0(0.0) \\
1(3.7) \\
2(7.4) \\
1(3.7) \\
0(0.0) \\
0(0.0) \\
1(3.7)\end{array}$ & $\begin{array}{c}0(0.0) \\
1(2.0) \\
10(20.0) \\
5(10.2) \\
0(0.0) \\
3(6.0) \\
9(18.0)\end{array}$ & $\begin{array}{c}4(4.8) \\
8(9.6) \\
2(2.4) \\
18(21.7) \\
1(1.2) \\
3(3.6) \\
11(13.3)\end{array}$ & $\begin{array}{l}0.293^{c} \\
0.195^{c} \\
0.002^{c} \\
\mathbf{0 . 0 3 5 ^ { a }} \\
0.633^{c} \\
0.208^{a}\end{array}$ \\
\hline ROM > 18 hours, $n(\%)$ & $27(17.0)$ & $3(11.1)$ & $7(14.0)$ & $17(20.7)$ & $0.408^{a}$ \\
\hline $\begin{array}{l}\text { Apgar score, } \mathrm{n}(\%) \\
\cdot 1^{\text {st }} \text { minute }<7 \\
\cdot 5^{\text {th }} \text { minute }<7 \\
\cdot 10^{\text {th }} \text { minute }<7\end{array}$ & $\begin{array}{c}108(68.4) \\
58(36.5) \\
13(9.8) \\
\end{array}$ & $\begin{array}{c}25(100.0) \\
15(57.7) \\
6(42.9) \\
\end{array}$ & $\begin{array}{c}37(74.0) \\
21(42.0) \\
3(7.7)\end{array}$ & $\begin{array}{c}46(55.4) \\
22(26.5) \\
4(5.1)\end{array}$ & $\begin{array}{c}<0.0005^{a} \\
0.01^{a} \\
<0.001^{c}\end{array}$ \\
\hline
\end{tabular}

Please note that in some cases data is missing.

BW: birth weight; GA: gestational age; IQR: interquartile range; ROM: rupture of membranes.

${ }^{\mathrm{a}}$ Chi-square test; ${ }^{\mathrm{b}}$ Kruskal-Wallis test; ${ }^{\mathrm{c}}$ Fisher's exact test.

Table 2. Management data of the newborns.

\begin{tabular}{|c|c|c|c|c|c|}
\hline GA (weeks) & $\begin{array}{c}\text { Total } \\
(n=160)\end{array}$ & $\begin{array}{c}23^{+0}-24^{+6} \\
(n=27)\end{array}$ & $\begin{array}{c}25^{+0}-26^{+6} \\
(n=50)\end{array}$ & $\begin{array}{c}27^{+0}-28^{+6} \\
(n=83)\end{array}$ & p \\
\hline Resuscitation, n (\%) & $153(95.6)$ & $26(96.3)$ & $49(98.0)$ & $78(94.0)$ & $0.681^{c}$ \\
\hline - Endotracheal tube, n (\%) & $141(92.2)$ & $26(100)$ & $45(91.8)$ & $70(89.7)$ & $0.258^{c}$ \\
\hline Surfactant use, n (\%) & $150(94.9)$ & $27(100)$ & $49(98.0)$ & $74(91.4)$ & $0.118^{c}$ \\
\hline - No. of doses, median (IQR) & $2(1-2)$ & $2(1.75-2.25)$ & $2(2-3)$ & $2(1-2)$ & $0.028^{b}$ \\
\hline$\cdot<1^{\text {st }}$ hour after birth, $\mathrm{n}(\%)$ & $67(49.3)$ & $15(78.9)$ & $23(51.1)$ & $29(40.3)$ & $0.011^{a}$ \\
\hline Supplemental oxygen, $\mathbf{n}(\%)$ & $160(100)$ & $27(100)$ & $50(100)$ & $83(100)$ & - \\
\hline - Days $\mathrm{O}_{2}$, median (IQR) & $15(4-50)$ & $5(1-17)$ & $34(8-75)$ & $15(4-44)$ & $<0.0005^{b}$ \\
\hline - $\mathrm{FiO}_{2}$ max, median (IQR) & $45(30-80)$ & $100(60-100)$ & $60(45-100)$ & $30(21-50)$ & $<0.0005^{b}$ \\
\hline Ventilation, $\mathbf{n}(\%)$ & $160(100)$ & $27(100)$ & $50(100)$ & $83(100)$ & - \\
\hline - nCPAP, n (\%) & $113(70.6)$ & $4(14.8)$ & $33(66.0)$ & $76(91.6)$ & $<0.0005^{a}$ \\
\hline - Days of therapy, median (IQR) & $31(17-45)$ & $23(4-44)$ & $31(12-45)$ & $31(22-46)$ & $0.287^{b}$ \\
\hline - IMV, n (\%) & $143(89.4)$ & $27(100)$ & $48(96.0)$ & $68(81.9)$ & $0.038^{c}$ \\
\hline - Days of therapy, median (IQR) & $8(4-25)$ & $4(1-17)$ & $21(8-35)$ & $7(4-17)$ & $<0.0005^{b}$ \\
\hline Vasoactive amines use, $\mathrm{n}(\%)$ & $68(42.8)$ & $16(61.5)$ & $26(52.0)$ & 26 (31.3) & $0.007^{a}$ \\
\hline Antibiotic treatment, $\mathbf{n}(\%)$ & $156(100)$ & $25(100)$ & $49(100)$ & $82(100)$ & - \\
\hline - No. of cycles, median (IQR) & $2(1-4)$ & $1(1-2)$ & $3(2-4)$ & $2(2-4)$ & $0.0005^{b}$ \\
\hline \multicolumn{6}{|l|}{ Transfusions } \\
\hline - Erythocytes, n (\%) & $115(71.9)$ & $18(66.7)$ & $44(88)$ & $53(63.7)$ & $0.009^{a}$ \\
\hline - No., median (IQR) & $3(2-7)$ & $3(1-7)$ & $5(3-9)$ & $3(2-5)$ & $<0.001^{\mathrm{b}}$ \\
\hline - Platelets, n (\%) & $57(35.6)$ & $10(37.0)$ & $29(58.0)$ & $18(21.7)$ & $<0.0005^{a}$ \\
\hline - No., median (IQR) & $3(1-5)$ & $4(2-7)$ & $2(1-5)$ & $3(1-4)$ & $0.917^{b}$ \\
\hline
\end{tabular}

Please note that in some cases data is missing.

GA: gestational age; IMV: invasive mechanical ventilation; IQR: interquartile range; nCPAP: nasal continuous positive airway pressure.

${ }^{\mathrm{a}}$ Chi-square test; ${ }^{\mathrm{b}}$ Kruskal-Wallis test; ${ }^{\mathrm{c}}$ Fisher's exact test. 
Table 3. Mortality and causes of death.

\begin{tabular}{|c|c|c|c|c|c|}
\hline GA (weeks) & $\begin{array}{c}\text { Total } \\
(n=160)\end{array}$ & $\begin{array}{l}23^{+0}-24^{+6} \\
(n=27)\end{array}$ & $\begin{array}{l}25^{+0}-26^{+6} \\
(n=50)\end{array}$ & $\begin{array}{l}27^{+0}-28^{+6} \\
(n=83)\end{array}$ & $\mathbf{p}$ \\
\hline $\begin{array}{l}\text { Deceased, } \mathbf{n}(\%) \\
\text { Causes of death }\end{array}$ & $60(37.5)$ & $25(92.6)$ & $23(46.0)$ & $12(14.5)$ & $<0.0005$ \\
\hline - Pulmonary hypoplasia, n (\%) & $16(26.7)$ & $12(48.0)$ & $2(8.7)$ & $2(16.7)$ & \\
\hline - Pulmonary hemorrhage, $n(\%)$ & $3(5.0)$ & $1(4.0)$ & $1(4.3)$ & $1(8.3)$ & \\
\hline - Pneumonia, n (\%) & $3(5.0)$ & $0(0.0)$ & $2(8.7)$ & $1(8.3)$ & \\
\hline - Sepsis, n (\%) & $18(30.0)$ & $6(24.0)$ & $8(34.8)$ & 4 (33.3) & \\
\hline - Congenital heart disease, $\mathrm{n}(\%)$ & $2(3.3)$ & $0(0.0)$ & $1(4.3)$ & $1(8.3)$ & \\
\hline$\cdot$ IVH, n (\%) & $18(30.0)$ & $6(24.0)$ & $9(39.1)$ & $3(25.0)$ & \\
\hline $\begin{array}{l}\text { Early neonatal mortality, } \mathrm{n}(\%) \\
\text { Causes of death }\end{array}$ & $33(20.6)$ & $17(62.9)$ & $7(14.0)$ & $9(10.8)$ & $<0.05^{b}$ \\
\hline - Pulmonary hypoplasia, n (\%) & $15(45.5)$ & $12(70.6)$ & $1(14.3)$ & $2(22.2)$ & \\
\hline - Pulmonary hemorrhage, $n(\%)$ & $3(9.1)$ & $1(5.9)$ & $1(14.3)$ & $1(11.1)$ & \\
\hline - Pneumonia, n (\%) & $1(3.0)$ & $0(0.0)$ & $0(0.0)$ & $1(11.1)$ & \\
\hline - Sepsis, n (\%) & $3(9.1)$ & $1(5.9)$ & $0(0.0)$ & $2(11.1)$ & \\
\hline - Congenital heart disease, $n(\%)$ & $2(3.3)$ & $0(0.0)$ & $1(14.3)$ & $1(11.1)$ & \\
\hline - IVH, n (\%) & $9(27.3)$ & $3(17.6)$ & $4(57.1)$ & $2(22.2)$ & \\
\hline $\begin{array}{l}\text { Late neonatal mortality, } \mathrm{n}(\%) \\
\text { Causes of death }\end{array}$ & $21(13.1)$ & 7 (25.9) & $12(24.0)$ & $2(2.4)$ & $<0.05^{b}$ \\
\hline - Pulmonary hypoplasia, n (\%) & $1(4.8)$ & $0(0.0)$ & $1(8.3)$ & $0(0.0)$ & \\
\hline - Pneumonia, n (\%) & $2(9.5)$ & $0(0.0)$ & $2(16.7)$ & $0(0.0)$ & \\
\hline - Sepsis, n (\%) & $10(47.6)$ & $4(57.1)$ & $5(41.6)$ & $1(50.0)$ & \\
\hline •IVH, n (\%) & $8(38.1)$ & $3(42.9)$ & $4(33.3)$ & $1(50.0)$ & \\
\hline $\begin{array}{l}\text { Postneonatal mortality }{ }^{\mathrm{c}}, \mathrm{n}(\%) \\
\text { Causes of death }\end{array}$ & $6(3.8)$ & $1(3.7)$ & $4(8.0)$ & $1(1.2)$ & $>0.05^{b}$ \\
\hline - Sepsis, $\mathbf{n}(\%)$ & $5(83.3)$ & $1(100)$ & $3(75.0)$ & $1(100)$ & \\
\hline - IVH, n (\%) & $1(16.7)$ & $0(0.0)$ & $1(25.0)$ & $0(0.0)$ & \\
\hline
\end{tabular}

Please note that in some cases data is missing.

GA: gestational age; IVH: intraventricular hemorrhage.

${ }^{\text {a }}$ Chi-square test; ${ }^{\text {b }}$ Chi-square test, using Bonferroni correction; ${ }^{\text {c }}$ death occurring after the $28^{\text {th }}$ day until discharge.

study. Nosocomial sepsis was present in $89(55.6 \%)$ and PDA in $84(52.8 \%)$. When it comes to brain damage, IVH occurred in $69(43.1 \%), 41(59.4 \%)$ of them classified as severe IVH, while 27 (16.9\%) developed cPVL.

In this study, survival without major morbidity was $5 \%$. Among survivors, 41 (41\%) had BPD, mostly mild or moderate. Between the $52(52 \%)$ with PDA, $39(78 \%)$ were treated medically. Fifty-six babies $(56.0 \%)$ were discharged with ROP, 24 (42.9\%) classified as severe ROP (grade 2 or higher). Sixteen of them were born with 25 or 26 weeks. Severe NEC was diagnosed in 14 $(14 \%)$ premature infants, 11 of them belonging to $\mathrm{G} 27^{+0}-28^{+6}$. Forty-four (44\%) had IVH, 19 $(43.2 \%)$ of them classified as severe. Median NICU stay was around 70 days, ranging from 93 or 97 days in the first two groups to 63 days in the third group (Tab. 4).

\section{Discussion}

In this study, we analyzed the neonatal mortality and morbidities of a cohort of preterm infants less than 29 weeks of GA.
A study comparing nine countries in Europe, showed that Portugal had one of the lowest preterm natality rates and it was ranked fifth in the adjusted neonatal death rate [18].

Implementation of regionalized perinatal care and high-quality NICUs, along with advances in areas such as technology or delivery assistance have allowed major improvements in pediatric life support [19]. Therefore, as expected, the mortality rates have decreased over the years. Specifically in this level III NICU which belongs to the pediatric service of a university hospital in Porto, Portugal, the mortality rates of premature infants less than 29 weeks of GA was around $52 \%$ in the nineties [20], contrasting with the $37.5 \%$ verified in our 2005 to 2016 cohort. Nevertheless, this increase in survival does not necessarily come along with a reduction of morbidities, particularly neurological sequelae [19]. This mortality rate is slightly higher than in other countries [21], although we should consider that we included in this study only preterm infants born before 29 weeks of GA.

Overall early neonatal mortality was $20.6 \%$. We registered that in the $\mathrm{G} 23^{+0}-24^{+6}$, death was much more prevalent in the first week than 
Table 4. Neonatal morbidity among the survivors.

\begin{tabular}{|c|c|c|c|c|c|}
\hline GA (weeks) & $\begin{array}{c}\text { Total } \\
(n=100)\end{array}$ & $\begin{array}{c}23^{+0}-24^{+6} \\
(n=2)\end{array}$ & $\begin{array}{l}25^{+0}-26^{+6} \\
(\mathrm{n}=27)\end{array}$ & $\begin{array}{l}27^{+0}-28^{+6} \\
(n=71)\end{array}$ & p \\
\hline RDS & $89(89.0)$ & $2(100)$ & $25(92.6)$ & $62(87.3)$ & $0.780^{a}$ \\
\hline - Moderate, n (\%) & $38(38.0)$ & $1(50.0)$ & $8(38.1)$ & $29(47.5)$ & $<0.0005^{b}$ \\
\hline - Severe, n (\%) & $25(25.0)$ & $1(50.0)$ & $13(61.9)$ & $11(18.0)$ & \\
\hline BPD, n (\%) & $41(41.0)$ & $2(100.0)$ & $19(70.4)$ & $20(28.2)$ & $<0.0005^{b}$ \\
\hline - Mild, n (\%) & $24(58.5)$ & $1(50.0)$ & $9(47.4)$ & $14(70.0)$ & \\
\hline - Moderate, n (\%) & $14(34.1)$ & $1(100)$ & $8(42.1)$ & $5(25.0)$ & $0.561^{\mathrm{b}}$ \\
\hline - Severe, n (\%) & $3(7.3)$ & $0(0.0)$ & $2(10.5)$ & $1(5.0)$ & \\
\hline Pneumonia, n (\%) & $9(9.0)$ & $0(0.0)$ & $8(29.6)$ & $1(1.4)$ & $<0.0005^{b}$ \\
\hline Pulmonary hemorrhage, n (\%) & $1(1.0)$ & $0(0.0)$ & $1(3.7)$ & $0(0.0)$ & $0.290^{b}$ \\
\hline Pneumothorax, n (\%) & $4(4.0)$ & $0(0.0)$ & $3(11.1)$ & $1(1.4)$ & $0.136^{\mathrm{b}}$ \\
\hline \multicolumn{6}{|l|}{ Sepsis } \\
\hline - Early, n (\%) & $5(5.0)$ & $0(0.0)$ & $2(7.4)$ & $3(4.2)$ & $0.652^{b}$ \\
\hline - Late/nosocomial, n (\%) & $69(69.0)$ & $2(100)$ & $20(74.1)$ & 47 (66.2) & $0.663^{a}$ \\
\hline PDA, n (\%) & $52(52.0)$ & $2(100)$ & $17(63.0)$ & $33(46.5)$ & $0.108^{b}$ \\
\hline - Medical closure, n (\%) & $39(78.0)$ & $2(100.0)$ & $10(58.8)$ & $27(87.1)$ & $0.074^{b}$ \\
\hline - Surgical closure, n (\%) & $11(22.0)$ & $0(0.0)$ & $7(41.2)$ & $4(12.9)$ & \\
\hline NEC $\geq$ grade 2, n (\%) & $14(14.0)$ & $0(0.0)$ & $3(11.1)$ & $11(15.5)$ & $0.817^{b}$ \\
\hline ROP, n (\%) & $56(56.0)$ & $2(100)$ & $21(77.8)$ & $33(46.5)$ & $0.04^{b}$ \\
\hline$\cdot \geq$ grade $2, \mathrm{n}(\%)$ & $24(42.9)$ & $1(50.0)$ & $16(76.2)$ & $7(9.9)$ & $<0.0005^{b}$ \\
\hline \multicolumn{6}{|l|}{ Brain damage } \\
\hline - IVH, n (\%) & $44(44.0)$ & $1(50.0)$ & $17(63.0)$ & $26(36.6)$ & $0.037^{b}$ \\
\hline • $\geq$ grade $3, \mathrm{n}(\%)$ & $19(43.2)$ & $0(0.0)$ & $9(52.9)$ & $10(38.5)$ & $0.524^{b}$ \\
\hline - cPVL, n (\%) & $10(10.0)$ & $0(0.0)$ & $5(18.5)$ & $5(7.0)$ & $0.298^{b}$ \\
\hline NICU stay, median (IQR) & 70 (55-95) & $93(85-101)$ & $97(73-109)$ & $63(49-83)$ & $<0.0005^{c}$ \\
\hline
\end{tabular}

Please note that in some cases data is missing.

BPD: bronchopulmonary dysplasia; cPVL: cystic periventricular leukomalacia; GA: gestational age; IQR: interquartile range; IVH: intraventricular hemorrhage; NEC: necrotizing enterocolitis; NICU: Neonatal Intensive Care Unit; PDA: patent ductus arteriosus; RDS: respiratory distress syndrome; ROP: retinopathy of prematurity.

${ }^{a}$ Chi-square test; ${ }^{b}$ Fisher's exact test; ${ }^{c}$ Kruskal-Wallis test.

afterward (62.9\% vs. $25.9 \%)$. On the other hand, the majority of those born with 25 or 26 weeks of GA died after the first seven days $(24.0 \%$ vs. $14.0 \%)$. This might be explained by the causes of death observed in these groups with different GAs and consequently with different morbidities. The main cause of death in neonates born with 23 or 24 weeks of GA was pulmonary hypoplasia, which is a condition directly associated with their very low GA. The dominant cause of late neonatal death in the $\mathrm{G} 25^{+0}-26^{+6}$ was sepsis, a condition not directly involved with the GA but significantly related with a longer stay in the NICU and, of course, with the vulnerability of each newborn [22]. Among survivors, it is also clear that nosocomial sepsis decreases with GA, meeting our expectations. In 2010, this NICU changed some protocols in order to prevent nosocomial sepsis, and its rates have been decreasing since then [22]. In the management of these preterm infants we continue to implement better practices to increase more and more the survival without increasing their morbidities.

As mentioned before, the leading causes of death were IVH and sepsis, both contributing individually to $30 \%$ of all deaths. Infectious causes were also responsible for $30 \%$ of deaths in a cohort of extremely low birth weight (ELBW) infants from 1996 to 2014 in this tertiary care center [23].

The limit of viability is considered to be the GA at which more than $50 \%$ of the newborns survive. The Portuguese Neonatal Society, based on the National Registry of Very Low Birth Weight (VLBW) Infants, has established this limit at 25 weeks since 2004 and sensitively at $500 \mathrm{~g}$ of birth weight [24]. In this study, this limit was also at 25 weeks of GA. Below this GA, the so-called "gray zone" of viability [3], medical decisions vary intensively across countries and are somewhat controversial, which is a reason why they require a careful and individualized analysis $[3,4]$. In Portugal, palliative care is recommended for those born with less than 23 of GA [24]. In our study, premature infant born at $\mathrm{G} 23^{+0}-24^{+6}$ had a $92.6 \%$ mortality rate, similar to other studies in this center $[19,23]$, and $44 \%$ of them died in the first 24 hours after admission in the NICU, in line with the EPIPAGE-2 group and other studies $[23,25]$. This can be explained by decisions to withdraw intensive care, which can also justify the paradoxical low rates of morbidities in this group 
of patients. All these differences explain the great variability in mortality in preterm infants at the limit of viability.

Another important aspect is the limit of viability without major sequelae in more than $50 \%$ of survivors. In our study, that limit was established at 27 weeks.

More than $50 \%$ of $\mathrm{G} 23^{+0}-24^{+6}$ were twins. Multiple pregnancy is related to prematurity and in this study it was significantly associated with those with less than 24 weeks of GA [26].

In this cohort, a C-section was performed in $60.6 \%$ of all deliveries, and the number increased with GA. C-section was not associated with higher survival when adjusted to GA, comparably with EPICure and EXPRESS groups [27, 28].

Prenatal steroids were previously proven to be good for induction of fetal maturation and were introduced to medical practices around 1995 [29]. Just like in the EXPRESS group study, steroids were almost universally administrated (91.6\%), with $77.3 \%$ of mothers receiving a full cycle [30], although significantly less at 23 and 24 weeks of GA probably due to the doubts about their efficacy in those born with 23 weeks of GA.

In this study, $89.4 \%$ of the preterm infants received IMV without significant difference before and after 2010. Although it was expected an increase of non-invasive mechanical ventilation in recent years, probably these results are explained by the low GA of the studied group. Given the recent evolution of early respiratory care in the delivery room and NICUs, we all should work towards reducing the use of IMV.

Extremely preterm newborns within "gray zone" GA $\left(\mathrm{G} 23^{+0}-24^{+6}\right)$ were all immediately intubated after birth and started mechanical ventilation, just like in a study performed in this center [19].

Supplemental oxygen therapy was given to all newborns, with a median of 15 days and a maximum $\mathrm{FiO}_{2}$ of $45 \%$. We must still work towards reducing the intensity of oxygen therapy in an attempt to decrease morbidity rates [31, 32].

Surfactant therapy was commonly used in all neonates but its need in the first hour of life decreased with GA, from $78.9 \%\left(\mathrm{G} 23^{+0}-24^{+6}\right)$, to $51.1 \%\left(\mathrm{G} 25^{+0}-26^{+6}\right)$ to $40.3 \%$ in the last group $\left(\mathrm{G} 27^{+0}-28^{+6}\right)$, as expected. We found no relation between this therapy and mortality, similar to EPICure and EPIBEL studies [26, 27] but in contrast with others [28].

Death rates were not affected by surfactant therapy or prenatal steroids. However, and as expected, the chances of death decreased with an increase in GA and birth weight. Based on the $\mathrm{B}$ value $=0.355$, we can calculate and say that the chances of death decreased $64.5 \%$ for each additional week of GA.

Comparing with the Vermont Oxford Network, global rates of RDS were very similar and BPD had lower rates in our study in contrast with other morbidities like PDA, IVH or cPVL which were higher in our cohort [21].

Among survivors, care must be taken when interpreting data from the $\mathrm{G} 23^{+0}-24^{+6}$, as only two of them survived. The main morbidities were ROP $(56 \%)$, IVH (44\%) and BPD (41\%). IVH is a major neurologic morbidity and was clearly a major cause of death at all ages, accounting for $30 \%$ of them. When comparing the prevalence of severe IVH on all patients with its prevalence among survivors, we can reinforce its contribution to mortality ( $59.4 \%$ vs. $43.2 \%$ ), also seen in the EPIBEL study [26]. This is one of many reasons why we should focus further research on how to prevent death and neurologic sequelae caused by this condition.

Between those who survived, infants born with less than 27 weeks of GA needed longer stays in the NICU, which can be a risk factor to many complications, particularly infectious ones.

One of the three major limitations is the retrospective design of the study. Another limitation is the small cohort size from a single center. We should not generalize the results, especially when comparing to larger studies like EPICure, EPIBEL, EPIPAGE-2 or EXPRESS [25-28]. Large international studies are extremely more accurate to draw a conclusion on all these practices [33, 34]. Lastly, besides being a singlecenter study, is also a tertiary one, which may hold some selection bias and we have to be aware when comparing it with data from a whole country.

Despite all these limitations, single-center studies are nonetheless extremely helpful to the physicians who work in NICUs allowing them to share experience and consequently improve the management of these preterm infants.

\section{Conclusion}

Mortality rates in this preterm group remained high in spite of all the technological and scientific advances. Pulmonary conditions (RDS and BPD), sepsis and neurologic outcomes (ROP, IVH and (PVL) are still a major cause of morbidity. In 
line with other series, the limit of viability in this cohort of preterm infants is 25 weeks of GA. Prenatal, perinatal and postnatal care still all have a long road ahead, especially when it comes to these "gray zone" newborns.

\section{Declaration of interest}

The Authors declare no conflicts of interest. There was no funding to perform this study.

\section{References}

1. WHO; Howson C, Kinney M, Lawn J (Eds.). Born Too Soon: The Global Action Report on Preterm Birth. Geneva, Switzerland: World Health Organization, 2012.

2. INE. Estatísticas Demográficas, $2016\left(76^{\mathrm{a}}\right)$. Instituto Nacional de Estatística (INE), 2016.

3. Seri I, Evans J. Limits of viability: definition of the gray zone. J Perinatol. 2008;28(Suppl 1):S4-8.

4. Guillen U, Weiss EM, Munson D, Maton P, Jefferies A, Norman M, Naulaers G, Mendes J, Justo da Silva L, Zoban P, Hansen TW, Hallman M, Delivoria-Papadopoulos M, Hosono S, Albersheim SG, Williams C, Boyle E, Lui K, Darlow B, Kirpalani H. Guidelines for the Management of Extremely Premature Deliveries: A Systematic Review. Pediatrics. 2015;136(2):343-50.

5. MacDonald H. Perinatal care at the threshold of viability. Pediatrics. 2002;110(5):1024-7.

6. Ballard JL, Khoury JC, Wedig K, Wang L, Eilers-Walsman BL, Lipp R. New Ballard Score, expanded to include extremely premature infants. J Pediatr. 1991;119(3):417-23.

7. Fenton TR, Kim JH. A systematic review and meta-analysis to revise the Fenton growth chart for preterm infants. BMC Pediatr. 2013;13:59.

8. Flôr-de-Lima F, Rocha G, Guimaraes H. Impact of changes in perinatal care on neonatal respiratory outcome and survival of preterm newborns: an overview of 15 years. Crit Care Res Pract. 2012;2012:643246.

9. Sweet DG, Carnielli V, Greisen G, Hallman M, Ozek E, Plavka R, Saugstad OD, Simeoni U, Speer CP, Halliday HL. European consensus guidelines on the management of neonatal respiratory distress syndrome in preterm infants -2010 update. Neonatology. 2010;97(4):402-17.

10. Sweet DG, Carnielli V, Greisen G, Hallman M, Ozek E, Plavka R, Saugstad OD, Simeoni U, Speer CP, Vento M, Halliday HL. European Consensus Guidelines on the Management of Neonatal Respiratory Distress Syndrome in Preterm Infants - 2013 Update. Neonatology. 2013;103(4):353-68.

11. Sweet DG, Carnielli V, Greisen G, Hallman M, Ozek E, Plavka R, Saugstad OD, Simeoni U, Speer CP, Vento M, Visser GH, Halliday HL. European Consensus Guidelines on the Management of Respiratory Distress Syndrome - 2016 Update. Neonatology. 2017;111(2):107-25
12. Jobe AH, Bancalari E. Bronchopulmonary dysplasia. Am J Respir Crit Care Med. 2001;163(7):1723-9.

13. Bell MJ, Ternberg JL, Feigin RD, Keating JP, Marshall R, Barton L, Brotherton T. Neonatal necrotizing enterocolitis. Therapeutic decisions based upon clinical staging. Ann Surg. 1978;187(1):1-7.

14. Papile LA, Burstein J, Burstein R, Koffler H. Incidence and evolution of subependymal and intraventricular hemorrhage: a study of infants with birth weights less than 1,500 gm. J Pediatr. 1978;92(4):529-34.

15. Volpe J, Inder T, Perlman J. Preterm Intraventricular Hemorrhage/ Posthemorrhagic Hydrocephalus. In: Volpe J, Inder T, Darras B, Vries Ld, Plessis Ad, Neil J, Perlman J (Eds.). Volpe's Neurology of the Newborn. $6^{\text {th }}$ Edition ed. Philadelphia, PA: Elsevier, 2017.

16. Vries LD, Rennie JM. Preterm Brain Injury. In: Rennie JM, Roberton N (Eds.). Textbook of Neonatology. $3^{\text {rd }}$ ed. London: Churchill Livingstone, 1999.

17. The International Classification of Retinopathy of Prematurity revisited. Arch Ophthalmol. 2005;123(7):991-9.

18. Field D, Draper ES, Fenton A, Papiernik E, Zeitlin J, Blondel B, Cuttini M, Maier RF, Weber T, Carrapato M, Kollee L, Gadzin J, Van Reempts P. Rates of very preterm birth in Europe and neonatal mortality rates. Arch Dis Child Fetal Neonatal Ed. 2009;94(4): F253-6.

19. Rocha G, Guimaraes H. On the limit of viability extremely low gestational age at birth. Acta Med Port. 2011;24(Suppl 2):181-8.

20. Rocha G, Rocha A, Martins A, Silva G, Guedes B, Guimarães H. Aspectos Clínicos da Prematuridade Extrema Parte I-Morbilidade e Mortalidade Neonatais. Acta Pediatr Port. 2002;33(4):235-41.

21. Chee YY, Wong MS, Wong RM, Wong KY. Neonatal outcomes of preterm or very-low-birth-weight infants over a decade from Queen Mary Hospital, Hong Kong: comparison with the Vermont Oxford Network. Hong Kong Med J. 2017;23(4):381-6.

22. Almeida CC, Pissarra da Silva SMS, Flôr-de-Lima F, Guimaraes Pereira Areias MHF. Nosocomial sepsis: evaluation of the efficacy of preventive measures in a level-III neonatal intensive care unit. J Matern Fetal Neonatal Med. 2017;30(17):2036-41.

23. Duraes MI, Flor-de-Lima F, Rocha G, Soares H, Guimaraes H. Morbidity and mortality of preterm infants less than 26 weeks of gestational age. Minerva Pediatr. 2016 Jul 13. [Epub ahead of print].

24. Branco MR, Mimoso G. Limite da viabilidade 2014. Available at: www.spneonatologia.pt, last access: March 1', 2018.

25. Ancel PY, Goffinet F, Kuhn P, Langer B, Matis J, Hernandorena X, Chabanier P, Joly-Pedespan L, Lecomte B, Vendittelli F, Dreyfus M, Guillois B, Burguet A, Sagot P, Sizun J, Beuchee A, Rouget F, Favreau A, Saliba E, Bednarek N, Morville P, Thiriez G, Marpeau L, Marret S, Kayem G, Durrmeyer X, Granier M, Baud O, Jarreau PH, Mitanchez D, Boileau P, Boulot P, Cambonie G, Daude H, Bedu A, Mons F, Fresson J, Vieux R, Alberge C, Arnaud C, Vayssiere C, Truffert P, Pierrat V, Subtil D, D’Ercole C, Gire C, Simeoni U, Bongain A, Sentilhes L, Roze JC, Gondry J, Leke A, Deiber M, Claris O, Picaud JC, Ego A, Debillon T, Poulichet A, Coline E, Favre A, Flechelles O, Samperiz S, Ramful 
D, Branger B, Benhammou V, Foix-L'Helias L, Marchand-Martin

L, Kaminski M. Survival and morbidity of preterm children born at 22 through 34 weeks' gestation in France in 2011: results of the EPIPAGE-2 cohort study. JAMA Pediatr. 2015;169(3): 230-8.

26. Vanhaesebrouck P, Allegaert K, Bottu J, Debauche C, Devlieger H, Docx M, Francois A, Haumont D, Lombet J, Rigo J, Smets K, Vanherreweghe I, Van Overmeire B, Van Reempts P. The EPIBEL study: outcomes to discharge from hospital for extremely preterm infants in Belgium. Pediatrics. 2004;114(3):663-75.

27. Costeloe K, Hennessy E, Gibson AT, Marlow N, Wilkinson AR. The EPICure study: outcomes to discharge from hospital for infants born at the threshold of viability. Pediatrics. 2000;106(4): $659-71$.

28. Fellman V, Hellstrom-Westas L, Norman M, Westgren M, Kallen K, Lagercrantz H, Marsal K, Serenius F, Wennergren M. Oneyear survival of extremely preterm infants after active perinatal care in Sweden. JAMA. 2009;301(21):2225-33.

29. Effect of corticosteroids for fetal maturation on perinatal outcomes. NIH Consensus Development Panel on the Effect of Corticosteroids for Fetal Maturation on Perinatal Outcomes. JAMA. 1995;273(5):413-8.

30. EXPRESS Group. Incidence of and risk factors for neonatal morbidity after active perinatal care: extremely preterm infants study in Sweden (EXPRESS). Acta Paediatr. 2010;99(7):978-92.
31. Schmidt B, Whyte RK, Asztalos EV, Moddemann D, Poets C, Rabi Y, Solimano A, Roberts RS. Effects of targeting higher vs lower arterial oxygen saturations on death or disability in extremely preterm infants: a randomized clinical trial. JAMA. 2013;309(20):2111-20.

32. Stenson BJ, Tarnow-Mordi WO, Darlow BA, Simes J, Juszczak E, Askie L, Battin M, Bowler U, Broadbent R, Cairns P, Davis PG, Deshpande S, Donoghoe M, Doyle L, Fleck BW, Ghadge A, Hague W, Halliday HL, Hewson M, King A, Kirby A, Marlow N, Meyer M, Morley C, Simmer K, Tin W, Wardle SP, Brocklehurst $\mathrm{P}$. Oxygen saturation and outcomes in preterm infants. $\mathrm{N}$ Engl $\mathrm{J}$ Med. 2013;368(22):2094-104.

33. Zeitlin J, Manktelow BN, Piedvache A, Cuttini M, Boyle E, van Heijst A, Gadzinowski J, Van Reempts P, Huusom L, Weber T, Schmidt S, Barros H, Dillalo D, Toome L, Norman M, Blondel B, Bonet M, Draper ES, Maier RF. Use of evidence based practices to improve survival without severe morbidity for very preterm infants: results from the EPICE population based cohort. BMJ. 2016;354:i2976.

34. Edstedt Bonamy AK, Zeitlin J, Piedvache A, Maier RF, van Heijst A, Varendi H, Manktelow BN, Fenton A, Mazela J, Cuttini M, Norman M, Petrou S, Reempts PV, Barros H, Draper ES. Wide variation in severe neonatal morbidity among very preterm infants in European regions. Arch Dis Child Fetal Neonatal Ed. 2018 Jan 20. [Epub ahead of print]. 